\title{
Fertilizer and soil conditioner value of broiler manure biochars
}

\author{
Riikka Keskinen $^{1}\left[\right.$ (1) Jari Hyväluoma ${ }^{1,2} \cdot$ Lauri Sohlo $^{1,3} \cdot$ Hanna Help $^{4} \cdot$ Kimmo Rasa $^{1}$
}

Received: 10 May 2019 / Accepted: 3 August 2019 / Published online: 27 August 2019

(c) The Author(s) 2019

\begin{abstract}
Pyrolysis is an option for enhancing the sustainable management of broiler manure surpluses by producing a concentrated, hygienic char product with a fertilizer and soil conditioner value. In this study, the impacts of pyrolysis conducted at 350, 400 and $450{ }^{\circ} \mathrm{C}$ on total nutrient and harmful element concentrations in biochars derived from peat-bedded broiler manure were examined. Emphasis was placed on the availability of phosphorus (P). In addition, the pore structures of these biochars were explored using X-ray microtomography and image analysis. During pyrolysis, 35-50\%, 40-55\% and 35-45\% of the original carbon, nitrogen and sulfur contents, respectively, of the feedstock biomass were lost as volatiles. Mineral elements, including $\mathrm{P}$, were concentrated in the biochar. Although water-extractable $\mathrm{P}$ was found to be converted to less labile forms due to charring, the concentration effect and notable increase in sodium bicarbonate-extractable $\mathrm{P}$ rendered broiler manure biochars richer in total labile $\mathrm{P}$ in comparison with feedstock manure (7.1, 10.0, 11.1 and $14.8 \mathrm{~g}$ labile $\mathrm{P} \mathrm{kg}^{-1}$ in feedstock and biochars produced at 350,400 and $450{ }^{\circ} \mathrm{C}$, respectively). The pore volume of the micrometer-scale porosity of the broiler manure biochar was comparable to that found earlier in wood-based biochars. In comparison with wood-based biochars, the pore structure of broiler manure biochars was more versatile, and the pore size distribution was wider. Consequently, part of the porosity was too large to store plant-available water, which may reduce the potential of broiler manure biochars to improve soil water storage capacity.
\end{abstract}

Keywords Poultry manure $\cdot$ Pyrolysis $\cdot$ Soil amendment $\cdot$ Pore structure $\cdot$ Phosphorus availability

\section{Introduction}

In recent decades, the intensification and concentration of farm animal systems has created considerable regional manure surpluses (Mallin and Cahoon 2003; Potter et al. 2010). The consequent on-farm land applications of manure in quantities exceeding the acreage's need have led to pollution of soil, air and water due to accumulation and subsequent leaching of nutrients and metals, gaseous emissions of ammonia, methane and nitrous oxides, and the spreading of

Riikka Keskinen

riikka.keskinen@luke.fi

1 Natural Resources Institute Finland (Luke), Tietotie 4, 31600 Jokioinen, Finland

2 Present Address: Häme University of Applied Sciences, Mustialantie 105, 31310 Mustiala, Finland

3 Present Address: Pellon Group Oy, Yrittäjäntie 10, 62375 Ylihärmä, Finland

4 Department of Physics, Faculty of Science, University of Helsinki, 00014 Helsinki, Finland pathogenic microorganisms (Martinez et al. 2009). In pursuit of reducing environmental hazards and enhancing the sustainable use of manure, many countries have introduced regulatory measures controlling manure management (Oenema 2004; Sommer et al. 2013). The transport of manure from the surplus regions to areas in need of nutrient inputs is limited by high costs (Paudel et al. 2009). An alternative to direct land disposal is to exploit the excess manure for renewable energy generation (Cantrell et al. 2008; Dalólio et al. 2017; Florin et al. 2009; Otero et al. 2011).

The complete oxidation of manure via combustion concentrates nutrients in the ash, which can be used as fertilizer, but nitrogen and organic matter are lost in the process. Pyrolysis, meaning heating in the absence of oxygen, decomposes the manure into solid char, non-condensable gases (e.g. CO, $\mathrm{CO}_{2}, \mathrm{CH}_{4}, \mathrm{H}_{2}$ ) and a liquid fraction rich in hydrocarbons (bio-oil), which in addition to energy production, are feasible for numerous other applications (e.g. Laird et al. 2009; Libra et al. 2011). From an agricultural perspective, biochar has shown promise as a soil amendment (Atkinson et al. 2010; Jeffery et al. 2011). Since charring reduces the original 
volume of the manure and concentrates valuable nutrients such as phosphorus $(\mathrm{P})$, pyrolysis increases the economic transport distances for land application and ensures manure hygienization.

The mechanisms behind positive growth effects resulting from the incorporation of biochar into soil probably arise from an increase in soil $\mathrm{pH}$, the amount of available nutrients, cation exchange or water retention capacity, enhanced nutrient use efficiency or decreased soil mechanical resistance (Chan et al. 2007; Glaser et al. 2002). An additional advantage of soil amelioration with biochar is an increase in long-term carbon storage, which contributes to climate change mitigation (Woolf et al. 2010). However, crop response to soil biochar amendment is highly variable and dependent on the properties of both the biochar and the soil (Jeffery et al. 2011).

The characteristics of biochar are governed by the properties of the feedstock biomass (e.g. Novak et al. 2014; Zornosa et al. 2016). Biochars derived from manure are in general rich in inorganic nutrient elements and thus have potential to enhance soil fertility (Enders et al. 2012; Novak et al. 2013, 2014; Ro et al. 2010). Although variation between diets, production techniques and manure handling generates substantial variation in the manure properties, broiler manure is overall the richest in nutrients compared to different livestock manures (Christensen and Sommer 2013; Moore et al. 1995). In modern broiler production, the birds are kept on a litter bed of wood shavings, peat or straw, which is removed at the end of each growing cycle (Sommer and Christensen 2013; Sørensen et al. 2006). The manure is thus composed of feces, feathers and wasted feed mixed in a large amount of bedding, and is typically low in moisture (Christensen and Sommer 2013; Moore et al. 1995). The proportion of $P$ in broiler manure is especially high (N:P:K-6:2:3), which renders broiler manure biochars as potential P fertilizers (Chan et al. 2008; Nicholson et al. 1996; Szogi and Vanotti 2009).

In addition to the feedstock type, process parameters, especially the highest heating temperature used, affect the characteristics of the biochar (e.g. Kloss et al. 2012; Song and Guo 2012). In general, an increase in the maximum temperature reached increases $\mathrm{pH}$, ash content, surface area and aromatization, and thus the stability of the produced biochar, but decreases the surface functionality, and consequently the cation exchange capacity (Mukherjee et al. 2011; Novak et al. 2009, 2013). Increasing the heating temperature has also been shown to decrease the availability of inherent biochar nutrients due to mineral crystallization (Zornosa et al. 2016). To produce biochar for agricultural use targeting soil fertility enhancement, low production temperatures $\left(300-450{ }^{\circ} \mathrm{C}\right.$ ) are recommended (Song and Guo 2012; Wang et al. 2012).
There is scant amount of literature on the structure of manure-based biochars. For wood-based materials, Gray et al. (2014) proposed a physical pore model, which describes the evolution of biochar porosity in pyrolysis. According to this model, biochar porosity consists of stable residual porosity that is based on the cellular structure of the feedstock plants and the pyrogenetic nanoporosity that develops during the pyrolysis process. The first type of porosity is more relevant for soil amendments, as the pores are in a size range capable of storing plant-available water. Since manure-based biochars consist of several components, it is likely that they lack a similarly well-defined structure to that found in wood-based biochars, which calls for investigations into the internal structure of such biochars.

The effects of manure-based biochars on soil's physical properties have been found to differ from those of woodbased biochars. For example, a meta-analysis by Omondi et al. (2016) showed that manure-based biochars had a considerably smaller effect on the saturated hydraulic conductivity of soils. In addition, Lei and Zhang (2013) found that biochars improved the water holding capacity of soil, but at the same soil water potential, soil amended with wood biochar had higher water content than soil amended with dairy-manure biochar. As the water retention properties of soil rely on micrometer-scale porosity, these findings suggest that the pore-space characteristics of wood and manurebased biochars are dissimilar.

Comprehensive information on the nutritional value and physical properties of manure-based biochars is lacking, though these characteristics, with carbon sequestration potential, determine the overall usefulness of biochar amendments in agriculture. In this study, the total concentrations of nutrients and selected harmful elements, and the availability of $\mathrm{P}$ in pyrolyzed peat-bedded broiler manure were determined in increasing charring temperatures at a range aimed at producing biochar for agricultural use (350, 400 and $450{ }^{\circ} \mathrm{C}$ ). In addition, the pore structures of these broiler manure biochars were examined, using X-ray microtomography and image analysis. The aim was to assess the total value of broiler manure biochar as a fertilizer and soil conditioner.

\section{Materials and methods}

\subsection{Broiler manure}

The broiler manure used in the study was obtained from Biolan Oy (Eura, Finland), and it originated from their contracted producers in Western Finland. The manure was composed of broiler dung and slightly decomposed lightcolored Sphagnum peat. Before sampling, the manure had been stored outdoors in a clamp for one month. 
The collected manure, roughly 601 in volume, was thoroughly mixed, and the distribution of particle sizes was homogenized by passing the mass sequentially through sieves with $50 \mathrm{~mm}$ and $10 \mathrm{~mm}$ meshes. Thereafter, representative samples of the homogenized fresh manure were collected for laboratory analysis. The remaining manure was pre-dried at $60{ }^{\circ} \mathrm{C}$ for two days. The pre-dried manure was likewise sampled for later analysis.

\subsection{Pyrolysis process}

Pre-dried broiler manure was pyrolyzed in batch-type laboratory-scale slow pyrolysis equipment at the Natural Resources Institute Finland in Jokioinen. An aliquot of $500.0 \mathrm{~g}$ of the manure was weighed and placed spaciously into the reactor, which was indirectly heated by an electric oven controlled with a preset temperature program. The gas temperature within the reactor was recorded throughout the process by a thermocouple sensor (TCC-K-250-6.0-KY) at 1 min intervals. During the first $10 \mathrm{~min}$, the temperature of the reactor was slowly increased to $30^{\circ} \mathrm{C}$. Thereafter, the reactor temperature was raised steadily at a rate of $2{ }^{\circ} \mathrm{C} \mathrm{min}-1$ to the desired maximum temperature, which was maintained for $1 \mathrm{~h}$. Maximum temperatures of $350^{\circ} \mathrm{C}, 400{ }^{\circ} \mathrm{C}$ and $450{ }^{\circ} \mathrm{C}$ were used. Finally, the reactor was cooled by ventilation, and the amounts of produced char and liquid were determined by weighing. The quantity of gas was calculated as the difference between the original feedstock biomass and the sum of the masses of biochar and liquid. At each temperature, the pyrolytic run was performed in triplicate.

\subsection{Laboratory analysis}

Both fresh and pre-dried broiler manure samples were analyzed for bulk density, dry matter content, total $\mathrm{N}$ and water-soluble $\mathrm{N}$ and $\mathrm{P}$ concentrations. The pre-dried broiler manure and broiler manure biochar samples were subjected to analyses of $\mathrm{pH}$ and electrical conductivity (EC), total concentrations of ash, C, N, P, K, Ca, Mg, Cu, Zn, Fe, Mn, Al, $\mathrm{Cr}, \mathrm{Hg}, \mathrm{Pb}, \mathrm{Cd}, \mathrm{As}, \mathrm{Mo}, \mathrm{Co}, \mathrm{Ni}$ and $\mathrm{S}$, and fractionation of $\mathrm{P}$ reserves.

The bulk density $\left(\mathrm{g} \mathrm{m}^{-3}\right)$ was determined according to EN 13040, and dry matter content gravimetrically as the residue remaining after drying the sample at $105{ }^{\circ} \mathrm{C}$ for two days. The total concentration of $\mathrm{N}$ in the manures was analyzed, using the Kjeldahl method (Foss, Kjeltec 8400). The water-soluble ammonium- $\mathrm{N}\left(\mathrm{NH}_{4}-\mathrm{N}\right)$, nitrate- $\mathrm{N}\left(\mathrm{NO}_{3}-\mathrm{N}\right)$ and phosphate-P $\left(\mathrm{PO}_{4}-\mathrm{P}\right)$ were analyzed from 1:60 water extracts with a continuous flow analyzer (Lachat QuikChem IC +8000 Series/Skalar San ++ System). The total N in the water extracts was determined by Kjeldahl digestion, and the proportion of soluble organic $\mathrm{N}$ was calculated by subtracting the sum of the inorganic $\mathrm{N}$ fraction from the total $\mathrm{N}$.
The $\mathrm{pH}$ and EC were measured in a 1:5 suspension in deionized water. Ash content was determined by loss on ignition at $550{ }^{\circ} \mathrm{C}$, and total contents of $\mathrm{C}$ and $\mathrm{N}$ via dry combustion (Dumas method, Leco TruMac $\mathrm{CN}$ ). Total concentrations of $\mathrm{P}, \mathrm{K}, \mathrm{Ca}, \mathrm{Mg}, \mathrm{Cu}, \mathrm{Zn}, \mathrm{Fe}, \mathrm{Mn}, \mathrm{Al}, \mathrm{Cr}, \mathrm{Hg}$, $\mathrm{Pb}, \mathrm{Mo}, \mathrm{Co}, \mathrm{Ni}$ and $\mathrm{S}$ were analyzed by ICP-OES (Perkin Elmer Optima 8300), and those of $\mathrm{Cd}$ and As were analyzed by a graphite furnace AAS (Varian AA280Z), after aqua regia digestion (SFS-ISO 11466:2007). The $\mathrm{P}$ fractions were studied, using the modified Hedley method (Sharpley and Moyer 2000) as in Ylivainio et al. (2008). In brief, $1 \mathrm{~g} \mathrm{sam-}$ ples were subjected to sequential extractions at an extraction ratio of 1:60, starting with two water extraction steps $(4 \mathrm{~h}$ and $16 \mathrm{~h}$ ) and followed by $0.5 \mathrm{M} \mathrm{NaHCO}_{3}, 0.1 \mathrm{M} \mathrm{NaOH}$ and $1 \mathrm{M} \mathrm{HCl}$ extractions (16 h each). The inorganic $\mathrm{P}$ and total $\mathrm{P}$ (acquired after oxidative digestion) concentrations in the extractants were determined by a spectrophotometer (Shimadzu UV-120-02). The amount of organic P was calculated as the difference between total $\mathrm{P}$ and inorganic P. All laboratory analysis were conducted at the Luke laboratories in Jokioinen.

\subsection{X-ray microtomography and image analysis}

In total, 18 biochar samples were imaged with X-ray tomography. Two replicate samples were taken from each pyrolysis run: six samples from each temperature were imaged. Samples were scanned at the X-ray laboratory (Department of Physics, University of Helsinki), using microtomography equipment (Nanotom 180 NF) by PhoenixlX-Ray Systems and Services (Wunstorf, Germany; currently owned by GE Measurement and Control Solutions). The equipment consists of a nanofocus X-ray source with a tungsten target, a high-resolution computer-controlled sample stage and a CMOS flat panel X-ray detector (Hamamatsu Photonics, Japan) with $2304 \times 2304$ pixels, each $50 \mu \mathrm{m} \times 50 \mu \mathrm{m}$ in size.

All samples were scanned with a $40 \mathrm{kV}$ current and 325 $\mu \mathrm{A}$ charge at $1 \mu \mathrm{m} / \mathrm{voxel}$ resolution. Each scan consisted of $12002 \mathrm{D}$ projections taken with a $0.3^{\circ}$ angular step interval over a full $360^{\circ}$ rotation of the sample. Each $2 \mathrm{D}$ projection image was averaged from three individual exposures, each lasting $1250 \mathrm{~ms}$.

3 D reconstructions were made, using the NRecon Reconstruction program, version 1.6.10.2. (provided by the Bruker microCT manufacturer). The software used a cone-beam filtered back-projection based on the FDK algorithm. A ring artifact correction was applied when necessary, but no other filters were used, although some beam hardening was later found in some datasets.

$\mathrm{X}$-ray microtomography results in a 3D distribution of the $\mathrm{X}$-ray attenuation coefficient (adsorption or scattered) in the sample, which is related to the density and elemental composition of the material in question. For quantitative pore space 
analyses, this grayscale image was converted to binary form to segment the solid and void phases. Image processing was undertaken in several steps.

First, the grayscale image was denoised with the variance weighted (VaWe) mean filter (Gonzalez and Woods 2008; Turpeinen 2015) and the beam hardening artifact, which was removed by following the ideas presented by Halverson et al. (2005) and Iassonov and Tuller (2010). Thereafter, images were segmented into voids and solids by global thresholding. The threshold value was determined with an automatic approach described by Hyväluoma et al. (2018b), which is based on the methods of Otsu (1979) and Hapca et al. (2013). Finally, the binary image was processed with a majority filter (radius 2), and isolated solid objects larger than 1000 voxels were removed from the images.

The samples were structurally very heterogeneous, and some of the images contained large voids. This makes a fair comparison of samples difficult, as voids are not representatively present. To circumvent this problem, we limited our structural analysis to pore space where pore size was smaller than $100 \mu \mathrm{m}$. The pore size associated with each voxel was determined through morphological opening (erosion followed by dilation with a spherical structuring element) of the pore space, which corresponds to the hydraulic diameter of the pore (Hilpert and Miller 2001; Vogel and Roth 1998). This definition of pore size is suitable for water retention applications such as biochar use as soil amendment. The region of interest in subsequent image analyses excluded the pore voxels with a pore diameter greater than $100 \mu \mathrm{m}$.

The images were analyzed for porosity, pore size distribution and specific surface area. Pore size distribution was calculated by successive application of a morphological opening with increasing diameter of the structuring element. The specific surface area was calculated from the number of pore-to-solid transitions, using a method based on Minkowski functionals (Vogel et al. 2010).

\subsection{Statistical analysis}

Differences in the properties between the feedstock manure and the three biochars (BC350, BC400 and BC450) and product yields between temperatures were tested, using the analysis of variance (ANOVA), and individual means were compared by least significant difference (LSD). The significance level was set at $5 \%$.

\section{Results}

The broiler manure used as feedstock in the pyrolysis was received at a dry matter content of $(51 \pm 1) \%$, and its bulk density was $341 \pm 3 \mathrm{~kg} \mathrm{~m}^{-3}$. The fresh manure contained a total of $(2.28 \pm 0.02) \% \mathrm{~N}[(4.58 \pm 0.05) \%$ of dry matter

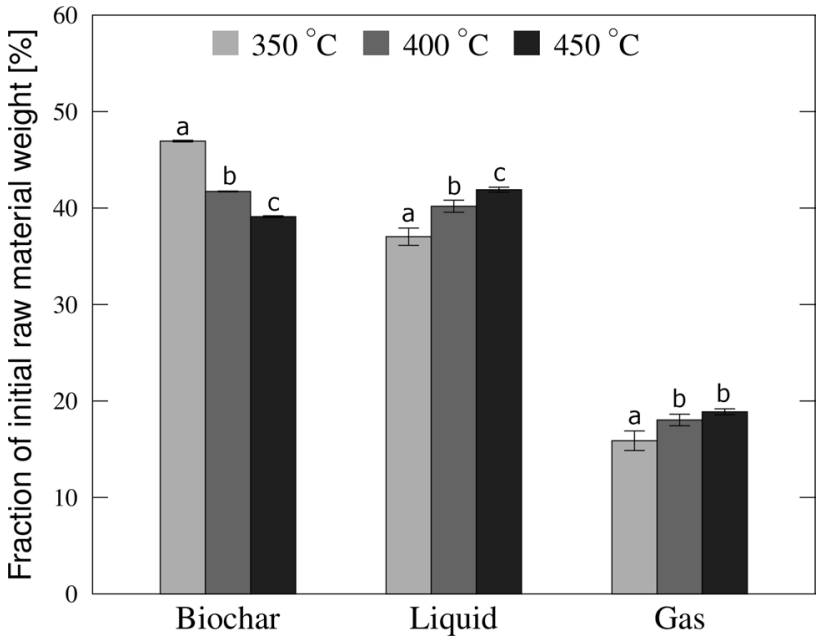

Fig. 1 Product yield distributions for peat-bedded broiler manure pyrolyzed at 350,400 and $450{ }^{\circ} \mathrm{C}$. Different letters indicate statistically significant differences within each product type at 0.05 level

(DM)]. The proportion of water-soluble N (1:60) of the total was $(59 \pm 2) \%$. Roughly $60 \%$ of the soluble $\mathrm{N}$ was acquired in organic form, and $40 \%$ as $\mathrm{NH}_{4}-\mathrm{N}$. The water-soluble $\mathrm{P}$ concentration was $1.9 \pm 0.1 \mathrm{~g} \mathrm{~kg}^{-1}$ fresh matter $(\mathrm{FM})$ and $3.9 \pm 0.2 \mathrm{~g} \mathrm{~kg}^{-1} \mathrm{DM}$. The $\mathrm{pH}$ of the fresh manure was $7.51 \pm 0.03$, and the EC $4.9 \pm 0.1 \mathrm{mS} \mathrm{cm}^{-1}$.

The two day pre-drying increased the manure dry matter content to $(92.9 \pm 0.1) \%$ and decreased the bulk density to $217 \pm 4\left(\mathrm{~kg} \mathrm{~m}^{-3}\right)$. The total $\mathrm{N}$ concentration in the pre-dried manure was $(3.43 \pm 0.11) \%$, but on a dry matter basis, $\mathrm{N}$ was lost during drying [(3.55 \pm 0.11$) \% \mathrm{~N}$ in $\mathrm{DM}]$. The proportion of water-soluble $\mathrm{N}$ of the total was $(57 \pm 3) \%$, and roughly $80 \%$ of the soluble $\mathrm{N}$ was found in organic form, and $20 \%$ as $\mathrm{NH}_{4}-\mathrm{N}$. The soluble $\mathrm{P}$ concentration in the pre-dried manure was $4.1 \pm 0.3 \mathrm{~g} \mathrm{~kg}^{-1} \mathrm{FM}$ and $4.3 \pm 0.3 \mathrm{~g} \mathrm{~kg}^{-1} \mathrm{DM}$.

Biochar was the main product of the pyrolysis process, followed by the liquid and gaseous fractions (Fig. 1). Of the original feedstock, dry matter (excluding the water content (ca. $7 \%$ ) of the feedstock), $50.6 \pm 0.1\left(350{ }^{\circ} \mathrm{C}\right), 45.1 \pm 0.0$ $\left(400{ }^{\circ} \mathrm{C}\right)$ and $(42.2 \pm 0.2) \%\left(450{ }^{\circ} \mathrm{C}\right)$ remained in the biochar. Due to charring, the ash content and concentrations of $\mathrm{Ca}, \mathrm{Co}, \mathrm{K}, \mathrm{Mg}, \mathrm{Mn}, \mathrm{Pb}, \mathrm{P}$ and $\mathrm{Zn}$ increased from the level found in the feedstock manure roughly in proportion to the loss of dry mass, meaning that the element concentrations were ca. 2, 2.2 and 2.4 times the level in the feedstock in the $\mathrm{BC} 350, \mathrm{BC} 400$ and BC450, respectively (Table 1). However, the concentrations of $\mathrm{Cd}, \mathrm{Cr}, \mathrm{Cu}, \mathrm{Fe}, \mathrm{Ni}$ and $\mathrm{S}$ found in the char were less than expected due to the concentration effect. Similarly, C and N were lost from the char fraction during pyrolysis. In contrast, the concentrations of $\mathrm{Al}$ and especially Mo seemed to increase more than the concentration effect. For As, high deviation between replicate samples rendered the results uncertain. The concentration of $\mathrm{Hg}$ was 
Table 1 Selected chemical properties of broiler manure feedstock and subsequent biochars (BC) after pyrolysis at 350,400 and $450{ }^{\circ} \mathrm{C}$

\begin{tabular}{|c|c|c|c|c|c|}
\hline Component & Feedstock & ВС350 & BC400 & BC450 & SE/LSD \\
\hline $\mathrm{C}(\%)$ & $42.2^{\mathrm{a}}$ & $53.1^{\mathrm{b}}$ & $52.1^{\mathrm{c}}$ & $53.0^{\mathrm{b}}$ & $0.2 / 0.7$ \\
\hline $\mathrm{N}(\%)$ & $4.0^{\mathrm{a}}$ & $4.8^{\mathrm{b}}$ & $4.3^{\mathrm{a}}$ & $4.2^{\mathrm{a}}$ & $0.1 / 0.3$ \\
\hline Ash (\%) & $15.1^{\mathrm{a}}$ & $30.0^{\mathrm{b}}$ & $33.6^{\mathrm{c}}$ & $35.3^{\mathrm{d}}$ & $0.1 / 0.4$ \\
\hline $\mathrm{pH}$ & $7.14^{\mathrm{a}}$ & $10.47^{\mathrm{b}}$ & $10.52^{\mathrm{c}}$ & $10.40^{\mathrm{d}}$ & $0.02 / 0.05$ \\
\hline $\mathrm{EC}\left(\mathrm{mS} \mathrm{cm}{ }^{-1}\right)$ & $3.7^{\mathrm{a}}$ & $5.4^{\mathrm{b}}$ & $6.7^{\mathrm{c}}$ & $6.8^{c}$ & $0.1 / 0.4$ \\
\hline $\mathrm{Al}\left(\mathrm{g} \mathrm{kg}^{-1} \mathrm{DM}\right)$ & $0.5^{\mathrm{a}}$ & $1.2^{\mathrm{b}}$ & $1.3^{\mathrm{b}, \mathrm{c}}$ & $1.4^{\mathrm{c}}$ & $0.1 / 0.15$ \\
\hline $\begin{array}{l}\text { As }\left(\mathrm{mg} \mathrm{kg}^{-1}\right. \\
\text { DM) }\end{array}$ & $1.1^{\mathrm{a}}$ & $4.1^{\mathrm{b}}$ & $1.8^{\mathrm{a}}$ & $2.6^{\mathrm{a}, \mathrm{b}}$ & $0.5 / 1.6$ \\
\hline $\mathrm{Ca}\left(\mathrm{g} \mathrm{kg}^{-1} \mathrm{DM}\right)$ & $14.5^{\mathrm{a}}$ & $30.5^{\mathrm{b}}$ & $34.5^{\mathrm{c}}$ & $36.6^{\mathrm{d}}$ & $0.2 / 0.7$ \\
\hline $\begin{array}{l}\mathrm{Cd}\left(\mathrm{mg} \mathrm{kg}^{-1}\right. \\
\mathrm{DM})\end{array}$ & $0.18^{\mathrm{a}}$ & $0.29^{\mathrm{b}}$ & $0.32^{\mathrm{c}}$ & $0.40^{\mathrm{d}}$ & $0.01 / 0.02$ \\
\hline $\begin{array}{l}\mathrm{Co}\left(\mathrm{mg} \mathrm{kg}^{-1}\right. \\
\mathrm{DM})\end{array}$ & $2.0^{\mathrm{a}}$ & $3.8^{\mathrm{b}}$ & $4.2^{\mathrm{c}}$ & $4.5^{\mathrm{d}}$ & $0.1 / 0.3$ \\
\hline $\begin{array}{l}\mathrm{Cr}\left(\mathrm{mg} \mathrm{kg}^{-1}\right. \\
\mathrm{DM})\end{array}$ & $18.9^{\mathrm{a}}$ & $30.9^{\mathrm{b}}$ & $36.5^{\mathrm{c}}$ & $39.2^{\mathrm{d}}$ & $0.7 / 2.4$ \\
\hline $\begin{array}{l}\mathrm{Cu}\left(\mathrm{mg} \mathrm{kg}^{-1}\right. \\
\mathrm{DM})\end{array}$ & $73.0^{\mathrm{a}}$ & $132.2^{\mathrm{b}}$ & $138.4^{\mathrm{c}}$ & $138.5^{\mathrm{c}}$ & $1.4 / 4.6$ \\
\hline $\mathrm{Fe}\left(\mathrm{g} \mathrm{kg}^{-1} \mathrm{DM}\right)$ & $1.4^{\mathrm{a}}$ & $2.5^{\mathrm{b}}$ & $2.6^{\mathrm{b}}$ & $2.9^{\mathrm{b}}$ & $0.2 / 0.6$ \\
\hline $\begin{array}{l}\mathrm{Hg}\left(\mathrm{mg} \mathrm{kg}^{-1}\right. \\
\text { DM) }\end{array}$ & na & $0.017^{\mathrm{a}}$ & $0.008^{\mathrm{b}}$ & $0.004^{c}$ & $0.001 / 0.003$ \\
\hline $\mathrm{K}\left(\mathrm{g} \mathrm{kg}^{-1} \mathrm{DM}\right)$ & $24.9^{\mathrm{a}}$ & $50.1^{\mathrm{b}}$ & $55.1^{\mathrm{c}}$ & $58.6^{\mathrm{d}}$ & $0.2 / 0.6$ \\
\hline $\operatorname{Mg}\left(\mathrm{g} \mathrm{kg}^{-1} \mathrm{DM}\right)$ & $8.2^{\mathrm{a}}$ & $15.5^{\mathrm{b}}$ & $17.2^{\mathrm{c}}$ & $18.1^{\mathrm{d}}$ & $0.1 / 0.4$ \\
\hline $\begin{array}{l}\mathrm{Mn}\left(\mathrm{mg} \mathrm{kg}^{-1}\right. \\
\mathrm{DM})\end{array}$ & $598^{\mathrm{a}}$ & $1157^{\mathrm{b}}$ & $1297^{c}$ & $1363^{\mathrm{d}}$ & $12 / 40$ \\
\hline $\begin{array}{l}\text { Mo }\left(\mathrm{mg} \mathrm{kg}^{-1}\right. \\
\text { DM) }\end{array}$ & $1.4^{\mathrm{a}}$ & $8.8^{\mathrm{b}}$ & $8.8^{\mathrm{b}}$ & $8.4^{\mathrm{b}}$ & $0.5 / 1.8$ \\
\hline $\begin{array}{l}\mathrm{Ni}\left(\mathrm{mg} \mathrm{kg}^{-1}\right. \\
\mathrm{DM})\end{array}$ & $13.3^{\mathrm{a}}$ & $22.8^{\mathrm{b}}$ & $25.8^{\mathrm{c}}$ & $27.6^{\mathrm{d}}$ & $0.4 / 1.2$ \\
\hline $\mathrm{P}\left(\mathrm{g} \mathrm{kg}^{-1} \mathrm{DM}\right)$ & $14.9^{\mathrm{a}}$ & $29.8^{\mathrm{b}}$ & $33.3^{\mathrm{c}}$ & $34.4^{\mathrm{d}}$ & $0.3 / 1.0$ \\
\hline $\begin{array}{l}\mathrm{Pb}\left(\mathrm{mg} \mathrm{kg}^{-1}\right. \\
\mathrm{DM})\end{array}$ & $1.6^{\mathrm{a}}$ & $2.9^{\mathrm{b}}$ & $3.8^{\mathrm{c}}$ & $4.2^{\mathrm{c}}$ & $0.1 / 0.5$ \\
\hline $\mathrm{S}\left(\mathrm{g} \mathrm{kg}^{-1} \mathrm{DM}\right)$ & $5.8^{\mathrm{a}}$ & $7.4^{\mathrm{b}}$ & $7.8^{\mathrm{c}}$ & $7.6^{c}$ & $0.1 / 0.16$ \\
\hline $\begin{array}{l}\mathrm{Zn}\left(\mathrm{mg} \mathrm{kg}{ }^{-1}\right. \\
\mathrm{DM})\end{array}$ & $393^{\mathrm{a}}$ & $828^{\mathrm{b}}$ & $951^{\mathrm{c}}$ & $990^{\mathrm{d}}$ & $8 / 25$ \\
\hline
\end{tabular}

The results are means of 3 replicates, standard error (SE) and least significant difference (LSD) within rows are shown in the last column na means not analyzed

Means with different letters within rows are statistically significant at a level of 0.05

not analyzed from the feedstock manure but only from the biochar, in which the $\mathrm{Hg}$ concentrations clearly decreased as the charring temperature increased. The produced biochars exhibited higher EC values and were prominently more alkaline than the feedstock manure.

The absolute $\mathrm{P}$ concentrations ( $\mathrm{mg} \mathrm{kg}^{-1} \mathrm{DM}$ ) were higher in the biochars than in the feedstock manure in all four fractions acquired by the Hedley method (Sharpley and Moyer 2000) except for the water extraction (Fig. 2). Relative distribution of aqua regia-extractable $\mathrm{P}$ among the fractions was affected by the pyrolysis treatment. In the feedstock manure, the water-soluble P fraction dominated (46\%), followed by the $\mathrm{NaOH}$-extractable $\mathrm{P}(16 \%)$, whereas the proportions of $\mathrm{NaHCO}_{3}$ - and $\mathrm{HCl}$-extractable $\mathrm{P}$ were marginal (1 and $3 \%$, respectively), and that of the residual $\mathrm{P}$ considerable (34\%). In the biochars, the $\mathrm{HCl}-$ fraction became pronounced (roughly $40 \%$ ), and the proportion of $\mathrm{NaHCO}_{3}$-extractable $\mathrm{P}$ increased to $20-25 \%$. On the other hand, the proportions of $\mathrm{NaOH}(10 \%)$ and especially water-extractable (10-15\%) and residual P (10-20\%) decreased from those in the feedstock manure. Besides the overall concentration effect rendering the total $\mathrm{P}$ concentration higher, the higher the pyrolysis temperature, is the impact of the maximum temperature applied on the relative proportions of $\mathrm{P}$ fractions in the biochars was small. The proportions of water-, $\mathrm{NaOH}$ - and $\mathrm{HCl}-$ extractable fractions showed no obvious trend by charring temperature, whereas the proportion of $\mathrm{NaHCO}_{3}$-extractable $\mathrm{P}$ tended to slightly increase, and that of residual $\mathrm{P}$ slightly decrease with an increasing temperature. Excluding the fraction of water-extractable $\mathrm{P}$, the relative proportion of organic $\mathrm{P}$ decreased due to charring the higher the charring temperature.

Visualizations of three selected samples imaged by X-ray microtomography are shown in Fig. 3. The visualizations show the organization of solids and voids in the samples. Individual reconstructed cross-sections of grayscale images are shown in Fig. 4. These cross-sections were taken from the same samples as in Fig. 3. Compared to the segmented images in Fig. 3, the grayscale images show the X-ray attenuation coefficient inside the samples.

Porosities determined from images (mean \pm standard deviation, $p=0.13$ ) were $0.50 \pm 0.06,0.50 \pm 0.10$ and $0.58 \pm 0.05$ for biochars pyrolyzed at 350,400 and $450{ }^{\circ} \mathrm{C}$, respectively. The specific surface areas were $69 \pm 11$, $76 \pm 16$ and $76 \pm 10 \mathrm{~mm}^{2} / \mathrm{mm}^{3}$ (from lowest to highest pyrolysis temperature, $p=0.51$ ). Pore size distributions are shown in Fig. 5. Pore size distributions appear to be very similar, irrespective of the pyrolysis temperature. The dominant pore diameter in all cases is around $10 \mu \mathrm{m}$, and distributions are positively skewed, with strong tails.

\section{Discussion}

\subsection{Chemical properties}

The properties of broiler manure are known to deviate with a wide range due to differences in diet, bedding material and production system. However, the $\mathrm{pH}$, ash content and total nutrient composition of the peat-bedded manure used as a feedstock in the current study accorded with the corresponding mean values reported for broiler manure in the literature (Cantrell et al. 2012; Edwards and Daniel 1992; Nicholson et al. 1996; Stephenson et al. 1990). Overall, broiler manure 
Fig. 2 Sequentially extracted fractions of $\mathrm{P}$ in feedstock broiler manure and subsequent biochars produced at 350,400 and $450{ }^{\circ} \mathrm{C}$
Fig. 3 X-ray tomographic reconstructions of three imaged samples which were pyrolyzed at $350{ }^{\circ} \mathrm{C}$ (left), $400{ }^{\circ} \mathrm{C}$ (middle) and $450{ }^{\circ} \mathrm{C}$ (right). The visualized volume is $1 / 8$ of the total imaged volume, as $1 / 4$ of the sample cross-section and $1 / 2$ of the axial length is shown in each case

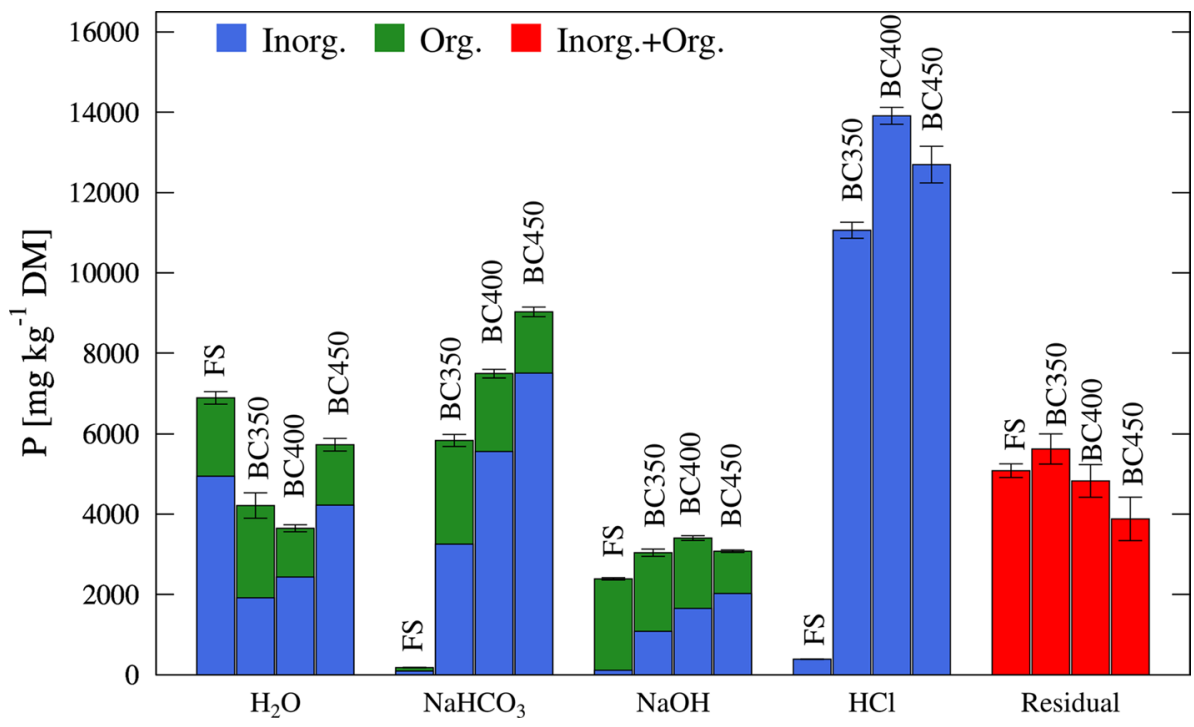

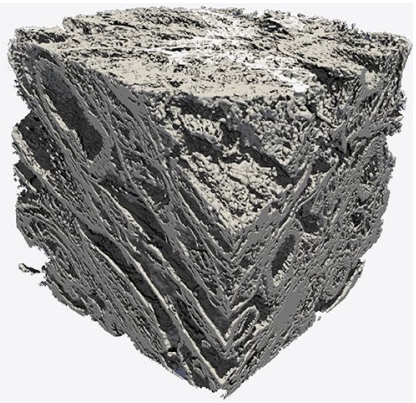
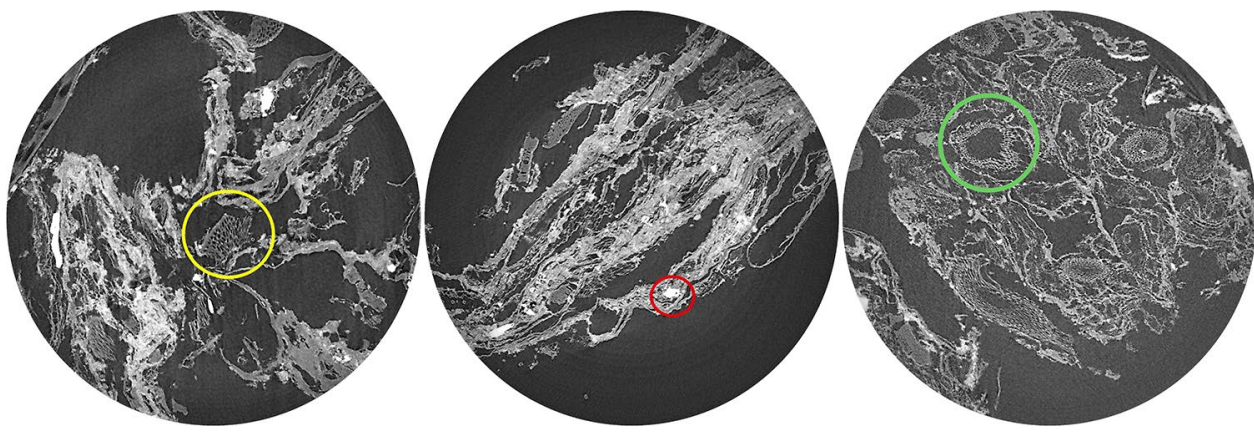

Fig. 4 Cross-sections of the grayscale images. A darker color indicates lower material density (e.g. air); higher density results are in a brighter color. The samples are as in Fig. 3. A yellow circle shows

constitutes a considerable source of macro- and micronutrients for crop production, though the nutrient balance is such that application rates based on crop $\mathrm{N}$ requirements tend to provide $\mathrm{P}$ and other nutrients in excess (Bolan et al. 2010). Elevated concentrations of metals may occur in poultry manure due to the use of different feed supplements (Nicholson et al. 1999). The metal concentrations in the feedstock manure of this study were at a moderate level. a non-digested grain, a red circle a small dense object (stone) and a green circle peat (bedding material). The diameter of each sample is $2.1 \mathrm{~mm}$ (color figure online)

In the pyrolysis process, the volatile fraction of biomass ends up in the non-condensable and condensable gases, while the non-volatile fraction is carbonized to biochar. Typical product distribution (weight \%) in slow pyrolysis (c. $400{ }^{\circ} \mathrm{C}$ ) is $35 \%$ char, $30 \%$ liquid and $35 \%$ gas, with the proportion of biochar decreasing as the reaction temperature increases (Libra et al. 2011). In the current study, the yields of char (39-47\%), liquid (37-42\%) and gas (16-19\%) differed somewhat from the average. Devolatilization and 

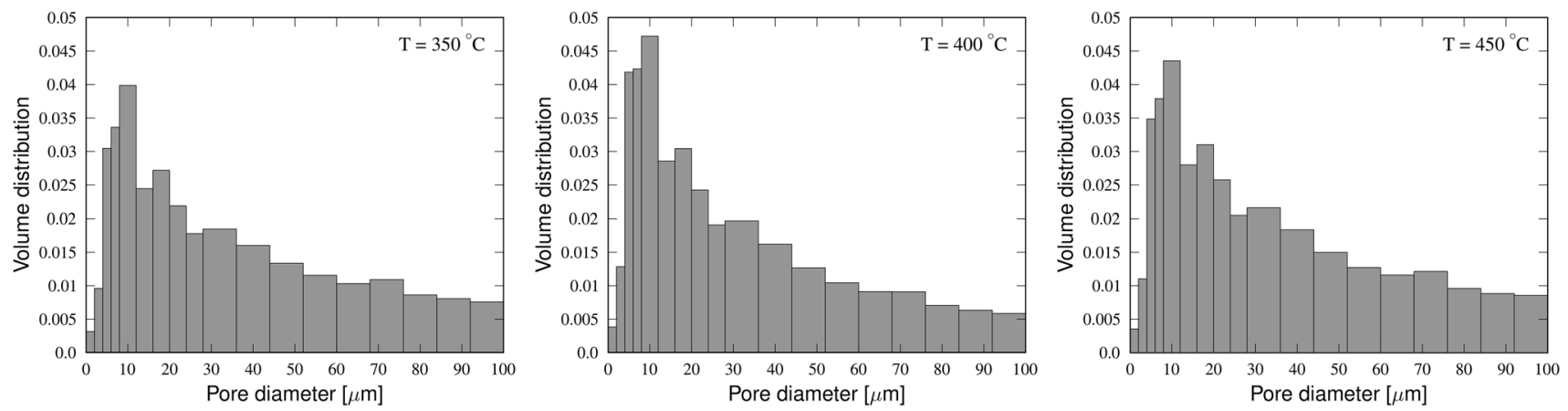

Fig. 5 Pore size distributions of biochars pyrolyzed at different temperatures. Distribution shown for each temperature merge the pore spaces of the six replicate samples

char conversion are known to be governed by the process conditions (temperature, pressure and heating rate), and the chemical composition and physical properties of the feedstock biomass (Demirbas 2004; Di Blasi et al. 1999). Di Blasi et al. (1999) showed agricultural residues produce much higher solid yields in comparison to wood, which is probably due to their higher contents of lignin and inorganics. In the study of Cantrell et al. (2012), biochar recoveries for manure-based feedstocks pyrolyzed at $350{ }^{\circ} \mathrm{C}$ exceeded $50 \%$, whereas Song and Guo (2012) reported poultry litter biochar recoveries of $49-56 \%$ at the temperature range used in this study.

Of the original $\mathrm{C}$ content in the feedstock broiler manure, roughly 35\% (BC350), 45\% (BC400) and 50\% (BC450) were volatilized during pyrolysis. The volatile $\mathrm{C}$ species include $\mathrm{CO}_{2}, \mathrm{CO}, \mathrm{CH}_{4}$ and other hydrocarbons of various lengths (data not shown). Similarly, considerable amounts of $\mathrm{N}$ (40\%, 50\% and 55\% of the amount in the feedstock) and S (35\%, $40 \%$ and $45 \%)$ were lost from the biochar fraction. Both $\mathrm{S}$ and $\mathrm{N}$ containing compounds are known to be converted into species emitted in gaseous form during pyrolysis (e.g. $\mathrm{NOx}, \mathrm{NH}_{3}, \mathrm{HCN}, \mathrm{HNCO}, \mathrm{SO}_{2}, \mathrm{H}_{2} \mathrm{~S}, \mathrm{COS}, \mathrm{CH}_{4} \mathrm{~S}$ ) (Ibarra et al. 1994; Paneque et al. 2017; Ren and Zhao 2012; Ro et al. 2010). The volatilization increases as the severity of the pyrolysis conditions increases (Song and Guo 2012), as evidenced in the present study. Cantrell et al. (2012) recorded $34 \%$ and $60 \%$ losses of $\mathrm{C}$ from the solid fraction after pyrolysis of poultry litter at 350 and $700{ }^{\circ} \mathrm{C}$, respectively. Corresponding losses for $\mathrm{N}$ were $34 \%$ and $79 \%$, and for S $43 \%$ and $60 \%$. In the study of Song and Guo (2012), the proportion of $\mathrm{C}$ lost as volatiles from poultry litter during pyrolysis increased from $35 \%$ to $60 \%$, and that of $\mathrm{N}$ from $20 \%$ to nearly $100 \%$, as the maximum process temperature increased from $300{ }^{\circ} \mathrm{C}$ to $600{ }^{\circ} \mathrm{C}$. In their study, the gaseous losses of $\mathrm{S}$ were negligible, regardless of the maximum temperature used. Ro et al. (2010) also reported low losses of S $(<10 \%)$ but similar to the other studies for C $(45 \%)$ and $\mathrm{N}(60 \%)$ from chicken litter during pyrolysis at $620^{\circ} \mathrm{C}$.
Despite the gaseous losses, the concentrations of $\mathrm{C}, \mathrm{N}$ and $\mathrm{S}$ in the biochars produced in the current study were higher in comparison to the feedstock, due to the total loss of biomass during pyrolysis.

As with $\mathrm{C}, \mathrm{N}$ and $\mathrm{S}$, smaller charring-induced increases than expected due to the concentration effect indicated minor losses (10-20\% of the original content in the feedstock biomass) of several metals $(\mathrm{Cd}, \mathrm{Cr}, \mathrm{Cu}, \mathrm{Fe}, \mathrm{Hg}$ and $\mathrm{Ni}$ ) from solid fraction. Volatilization of $\mathrm{Cd}$ and $\mathrm{Hg}$ at already relatively low pyrolysis temperatures is well known, but $\mathrm{Cr}, \mathrm{Cu}$, $\mathrm{Fe}, \mathrm{Ni}$ and $\mathrm{Pb}$ are not expected to be volatile at the temperature range applied in this study (e.g. Al Chami et al. 2014; Kistler et al. 1987; Lievens et al. 2008). Instead of volatilization, conversion of these elements to compounds that are non-soluble in the aqua regia extractant is more likely.

In contrast to the volatile elements, mineral nutrients $(\mathrm{Ca}$, $\mathrm{K}, \mathrm{Mg}, \mathrm{Mn}, \mathrm{P}$ and $\mathrm{Zn}$ ) were enriched in the biochar fraction in proportion to the loss of dry matter during pyrolysis. Increases in the excess of the concentration effect recorded for $\mathrm{Al}$ and especially Mo may indicate contamination of the char, e.g. from the pyrolysis equipment, or possibly an increase in the solubility of Al- and Mo-containing compounds in the aqua regia extractant. An increase in alkalinity with an increasing charring temperature is linked to the formation of carbonates (Yuan et al. 2011). Biochars derived from high-ash animal manures typically exhibit high $\mathrm{pH}$ values (e.g. Cantrell et al. 2012; Enders et al. 2012), and thus generate a positive liming effect in neutral and acidic soils (Chan et al. 2008).

The enrichment of nutrient elements as a result of pyrolysis can be considered to increase the fertilizer value of manure. However, the fertilizer value is ultimately governed by the plant availability of the nutrients. For N, pyrolysis has been shown to decrease plant availability drastically as the mobile inorganic $\mathrm{N}$ species are lost as volatiles, and the remaining organic $\mathrm{N}$ is bound to stable aromatic compounds (Paneque et al. 2017; Pels et al. 1995). Consequently, broiler 
manure biochar can be mainly regarded as a $\mathrm{P}$ fertilizer, which is why the mobility of $\mathrm{P}$ was a focus of this study.

\subsubsection{Availability of $P$}

Using the applied Hedley fractionation procedure, labile $\mathrm{P}$ that is easily available to plants (water and $\mathrm{NaHCO}_{3}$ extraction steps) can be distinguished from non-labile fractions tightly bound to unavailable forms $(\mathrm{NaOH}$ and $\mathrm{HCl}$ extraction steps and the residual $\mathrm{P}$, defined as the difference between aqua regia-extractable $\mathrm{P}$ and the sum of the individual $\mathrm{P}$ fractions) (Cross and Schlesinger 1995). In the feedstock manure used in this study, roughly $50 \%$ of the total (aqua regia-extractable) $\mathrm{P}$ was recovered in easily plant-available fractions and $50 \%$ in recalcitrant forms. Sharpley and Moyer (2000) and Dou et al. (2000) reported a somewhat higher proportion (60-70\%) of labile P for poultry manure. Their material, with no or a very low amount (10\%) of bedding contained $28 \%$ and $50 \%$ water soluble P and $35 \%$ and $20 \% \mathrm{NaHCO}_{3}$-extractable $\mathrm{P}$, the latter differing notably from the negligible proportion recorded for the manure with high bedding content in this study. As for the recalcitrant fractions, we recorded a higher proportion of $\mathrm{NaOH}-$ extractable P (16\%) than Sharpley and Moyer (2000) and Dou et al. (2000) (7\% and 5\%, respectively). In the current study, $\mathrm{HCl}$ extractant was clearly inefficient against the most stable forms of $\mathrm{P}$ in the manure, since they remained largely in the residual fraction (3\% $\mathrm{HCl}$-extractable, 34\% residual $\mathrm{P}$ ), which was the opposite of the results of the previous studies (25-30\% $\mathrm{HCl}$-extractable, $2 \%$ residual P; Sharpley and Moyer 2000; Dou et al. 2000). The proportions of organically bound $\mathrm{P}$ were generally higher in the manure of the current study than those recorded in the previous studies (Sharpley and Moyer 2000; Dou et al. 2000).

When the amount of labile $\mathrm{P}$ in the original batch of feedstock and in the corresponding amount of biochar produced are compared, a conversion of $\mathrm{P}$ to less labile forms due to charring can be observed. In the BC350 and BC400, the yield of labile $\mathrm{P}$ (water and $\mathrm{NaHCO}_{3}$ extraction steps) was $30 \%$ less and in $\mathrm{BC} 45010 \%$ less than in the original amount of pyrolyzed feedstock biomass. However, on an equal mass basis, the amount of labile $\mathrm{P}$ increased as a result of pyrolysis, the higher the maximum process temperature applied (labile P concentrations were 7.1, 10.0, 11.1 and $14.8 \mathrm{~g} \mathrm{~kg}^{-1}$ in the feedstock, BC350, BC400 and BC450, respectively). Both the concentration and relative proportion of water-extractable $\mathrm{P}$ were, however, lower in the biochars than in the feedstock manure. Yet in the current biochars, the amount of $\mathrm{NaHCO}_{3}$-extractable $\mathrm{P}$, also considered plantavailable, increased 30-50-fold from the level in the feedstock. A pyrolysis-induced decrease in water-extractable $\mathrm{P}$ was also observed by Wang et al. (2015) for poultry litter and Cao and Harris (2010) for dairy manure. These authors suggested the decrease in $\mathrm{P}$ mobility was the result of the conversion of labile $\mathrm{P}$ to $\mathrm{Mg}$ and $\mathrm{Ca}$ phosphate minerals. Wang et al. (2015) found that the release of P from poultry litter biochars was an acid-driven process. They recorded a steady release of $\mathrm{P}$ following the incorporation of poultry litter biochar into a slightly acidic soil ( $\mathrm{pH}$ 6.5). The true bioavailability of $\mathrm{P}$ in the current broiler manure biochars needs to be experimentally confirmed with plants grown in various soil types, but the results of this study imply that water extraction alone may not be appropriate for assessing the bioavailability of P in biochars. Wang et al. (2012) recommended extraction with $2 \%$ formic acid for assessing the biochar $\mathrm{P}$ availability.

In the current study, the relative proportion of $\mathrm{NaOH}$ extractable $\mathrm{P}$ was lower in the biochars than in the feedstock manure. This may result from thermochemical decomposition of organic $\mathrm{P}$ compounds since $95 \%$ of the $\mathrm{P}$ acquired in this fraction from the feedstock manure was organically bound. In the biochars, $\mathrm{HCl}$ mobilized the stable P relatively more efficiently than in the feedstock manure, as the proportion of residual $\mathrm{P}$ from the total $\mathrm{P}$ decreased to $10-20 \%$ in the biochars.

\subsection{Physical properties}

Visual inspection of the 3D visualizations and cross-sections (Figs. 3,4 ) showed that the samples were structurally heterogeneous and contained various components like non-structural excrements, bedding material and other straws, nondigested grains and some high-density particles (perhaps small stones). Thus, the pore spaces are composed of (1) cellular structures of plants and tissues, (2) voids of various sizes in the non-structural materials and (3) voids between different components. Contrary to our initial estimate, none of the imaged biochar particles were pure bedding material, but the different components surprisingly seemed evenly mixed. While X-ray microtomography has been used to image biochar derived from plant-based materials (Berhanu et al. 2018; Bird et al. 2008; Hyväluoma et al. 2018b; Jeffery et al. 2015; Jones et al. 2015; Schnee et al. 2016), to our knowledge this is the first study using X-ray microtomography to study the structure of broiler manure biochar. Previously, scanning electron microscopy (SEM) has been used to visually study the structure of broiler manure biochar (Glazunova et al. 2018; Liang et al. 2016; Lima et al. 2015; Qiu and Guo 2010; Song and Guo 2012). For example, the porous structures in the SEM images presented by Lima et al. (2015) originate from the cellular structure of wood. They, therefore, do not represent the manure biochar but the bedding material (wood shavings).

In a previous study, X-ray microtomography with virtually the same resolution was used to determine porosities for biochars derived from wood (Hyväluoma et al. 2018b; Rasa 
et al. 2018). The porosities of broiler manure biochars were in the same range as those obtained for wood-based biochars (0.34-0.67), even though the scope of interest in the present study excludes pores larger than $100 \mu \mathrm{m}$ in diameter. While there was no statistically significant difference between the porosities of the current chars pyrolyzed at different temperatures, the porosity of biochar produced at $450{ }^{\circ} \mathrm{C}$ was higher than those produced at lower temperatures. This suggests that the structure of manure-based biochars may start to develop at lower temperatures than those of wood-based materials (cf. e.g. Berhanu et al. 2018; Hyväluoma et al. 2018a). However, further research on this topic is required.

The shape of pore size distributions differed from those obtained for wood-based materials, which were considerably less skewed, and the pore sizes were limited to less than $60 \mu \mathrm{m}$ (Hyväluoma et al. 2018b; Rasa et al. 2018). While the pore space of wood-based biochars originates from the cellular structure of the raw materials, manure-based biochars have a more versatile pore structure and thus wider pore size distribution. In the case of wood biochar, the pore structure is considered relatively strong against physical stresses. However, how well broiler manure-based biochars retain their initial structure when subjected to various stresses in soil is not known.

The specific surface areas were somewhat lower than those reported previously for wood-based biochars $\left(87-142 \mathrm{~mm}^{2} / \mathrm{mm}^{3}\right.$ ) (Hyväluoma et al. 2018b). This stems from the different pore size distributions: larger pores present in the broiler manure biochar produce a small surface area compared to a situation where the same porosity is formed of smaller pores (e.g. organized wood tracheary elements). Previously, the surface area of broiler manure biochar has been determined by gas adsorption techniques, which probe different pore size regimes (nanometer-range pores) than we studied with X-ray microtomography. However, gas adsorption measurements also showed only a negligible growth in the surface area in the temperature range used in the present study (Song and Guo 2012).

\subsection{Fertilizer and soil conditioner value}

At an application rate of $1 \mathrm{t} \mathrm{ha}^{-1}$, the produced broiler manure biochars would provide $30-35 \mathrm{~kg}$ of total $\mathrm{P}$ (in a range from the lowest to highest process temperature), of which 10-15 kg would be directly in plant-available form. The reserves of $\mathrm{P}$ in broiler manure biochar are probably released more slowly than from the raw manure feedstock, which may promote efficient $\mathrm{P}$ uptake by crops and serve to minimize $\mathrm{P}$ runoff losses to the environment (Wang et al. 2015). For $\mathrm{N}$, the $1 \mathrm{t} \mathrm{ha}^{-1}$ biochar amendment would lead to an addition of $40-50 \mathrm{~kg} \mathrm{~N}$, but due to the recalcitrant nature of the char $\mathrm{N}$, it should be considered as having a mainly slow-release value (Paneque et al. 2017). The corresponding inputs for other mineral macronutrients would be $30-40 \mathrm{~kg}$ $\mathrm{Ca}, 50-60 \mathrm{~kg} \mathrm{~K}, 15-20 \mathrm{~kg} \mathrm{Mg}$ and circa $8 \mathrm{~kg} \mathrm{~S}$. In addition, the biochar application would contain valuable micronutrients (e.g. 140 g Cu, 900 g Zn, 1300 g Mn). However, according to Zornosa et al. (2016), Song and Guo (2012) and Wang et al. (2015), the instant bioavailability of these nutrients excluding $\mathrm{K}$ and $\mathrm{S}$ may be quite low. The amounts of harmful metals introduced per hectare within $1 \mathrm{t}$ of the current biochars (3 g As, $0.3 \mathrm{~g} \mathrm{Cd}, 35 \mathrm{~g} \mathrm{Cr},<0.02 \mathrm{~g} \mathrm{Hg},<30 \mathrm{~g}$ $\mathrm{Ni}$ and $<4 \mathrm{~g} \mathrm{~Pb}$ ) would be tolerable even in a vulnerable environment (MAF, Ministry of Agriculture and Forestry (Finland) 2018). Besides, biochars tend to immobilize metals, thus reducing their availability to plants (Kistler et al. 1987; Park et al. 2011).

Due to the high $\mathrm{P}$ content of broiler manure biochars, their sustainable application rates remain much lower than those applicable to nutrient-poor wood-based biochars. The input of $\mathrm{C}$ within an amendment of $1 \mathrm{t} \mathrm{ha}^{-1}$ of broiler manure biochar would be merely $420-530 \mathrm{~kg}$, whereas an application of $30 \mathrm{t} \mathrm{ha}^{-1}$ of wood-based biochar would provide only around $150 \mathrm{~kg} \mathrm{~N}$ and $15 \mathrm{~kg} \mathrm{P}$, but 20-25 t of C (Mukome et al. 2013). Furthermore, high-ash biochars produced at low temperatures, like the present broiler manure biochars, tend to degrade more rapidly in soil than more recalcitrant woodbased biochars (Enders et al. 2012; Spokas 2010; Wang et al. 2016). The $\mathrm{C}$ sequestration potential of broiler manure biochars can thus be regarded as low. However, amendments of labile biochar have been found to increase microbial activity in soil (e.g. Ameloot et al. 2013), which may be reflected positively in nutrient use efficiency and soil structure stabilization. Jeffery et al. (2011) suggested that the main mechanisms related to biochar-induced yield increases would be an improved crop nutrient-availability, a liming effect and the increased water holding capacity of the receiving soil.

The low sustainable application rate of broiler manure biochar limits its utility in improving the water holding capacity, at least as long as the so-called direct mechanism (Verheijen et al. 2010), where water is directly stored in biochar pores, is responsible for the improved water retention properties. Laghari et al. (2015) tested the ability of wood-based biochar to improve the water holding capacity of desert soils and found that higher application rates led to a greater increase in water holding capacity. Brewer et al. (2012), on the other hand, found no statistically significant effect of added biochar on water retention properties and supposed that their application rate was not sufficiently high to produce such an influence. However, the use of nutrientrich biochars will probably be based on repetitive applications. A repeated application might increase the water holding capacity over the years, as an increasing amount of stable carbon is accumulated in the soil, as suggested by Schmidt et al. (2017). 


\section{Conclusions}

In conclusion, our results indicate that pyrolysis is a feasible option for enhancing the sustainable use of broiler manure as a $\mathrm{P}$ fertilizer and soil conditioner. Although $\mathrm{C}, \mathrm{N}$ and $\mathrm{S}$ are partially lost in the process, mineral nutrients, especially $\mathrm{P}$, are concentrated in a dry and hygienized product which is more economically transported than the original feedstock. The concentration effect with an increase in the proportion of $\mathrm{NaHCO}_{3}$-extractable $\mathrm{P}$ rendered broiler manure biochars richer in labile $\mathrm{P}$ compared with the feedstock manure on an equal mass basis. Imaging of the broiler manure biochars revealed a pore structure that differed from that in woodderived biochars. Broiler manure biochars had a wider pore size distribution and contained pores that were larger than those in wood-based biochars. Water stored in these larger pores can easily be drained by gravity, and they are thus not necessarily useful in biochars aimed at improving soil's water retention properties. In spite of this, the main part of the porosity in the investigated biochars was in the pore size regime that could store plant-available water. The highest end of the applied temperature range $\left(350-450{ }^{\circ} \mathrm{C}\right)$ seemed to produce biochar with both the highest labile $\mathrm{P}$ concentrations and highest porosity.

Acknowledgements Open access funding provided by Natural Resources Institute Finland (LUKE). We wish to thank Biolan Oy for providing us the feedstock broiler manure and Luke's technical staff for their skilled laboratory analyses. We acknowledge the University of Helsinki Micro-CT Laboratory for their X-ray tomography imaging. This work was supported by the Nutrient Recycling Pilot Programme coordinated by the Centre for Economic Development, Transport and the Environment, Finland. Hanna Help was supported by the Academy of Finland (Grant 1295696).

Open Access This article is distributed under the terms of the Creative Commons Attribution 4.0 International License (http://creativeco mmons.org/licenses/by/4.0/), which permits unrestricted use, distribution, and reproduction in any medium, provided you give appropriate credit to the original author(s) and the source, provide a link to the Creative Commons license, and indicate if changes were made.

\section{References}

Al Chami Z, Amer N, Smets K, Yperman J, Carleer R, Dumontet S, Vangronsveld J (2014) Evaluation of flash and slow pyrolysis applied on heavy metal contaminated Sorghum bicolor shoots resulting from phytoremediation. Biomass Bioenergy 63:268-279

Ameloot N, Graber ER, Verheijen FGA, De Neve S (2013) Interactions between biochar stability and soil organisms: review and research needs. Eur J Soil Sci 64:379-390

Atkinson CJ, Fitzgerald JD, Hipps NA (2010) Potential mechanisms for achieving agricultural benefits from biochar application to temperate soils: a review. Plant Soil 337:1-18

Berhanu S, Hervy M, Weiss-Hortala E, Proudhon H, Berger M-H, Chesnaud A, Faessel M, King A, Minh DP, Villot A, Gérente C, Thorel A, LeCoq L, Nzihou A (2018) Advanced characterization unravels the structure and reactivity of wood-based chars. J Anal Appl Pyrol 130:79-89

Bird MI, Ascough PL, Young IM, Wood CV, Scott AC (2008) X-ray microtomographic imaging of charcoal. J Archaeol Sci 35:2698-2706

Bolan NS, Szogi AA, Chuasavathi T, Seshadri B, Rothrock MJ Jr, Panneerselvam P (2010) Uses and management of poultry litter. Worlds Poult Sci J 66:673-698

Brewer CE, Hu YY, Schmidt-Rohr K, Loynachan TE, Laird DA, Brown RC (2012) Extent of pyrolysis impacts on fast pyrolysis biochar properties. J Environ Qual 41:115-1122

Cantrell KB, Ducey T, Ro KS, Hunt PG (2008) Livestock waste-to-bioenergy generation opportunities. Bioresour Technol 99:7941-7953

Cantrell KB, Hunt PG, Uchimiya M, Novak JM, Ro KS (2012) Impact of pyrolysis temperature and manure source on physicochemical characteristics of biochar. Bioresour Technol 107:419-428

Cao X, Harris W (2010) Properties of dairy-manure-derived biochar pertinent to its potential use in remediation. Bioresour Technol 101:5222-5228

Chan KY, Van Zwieten L, Meszaros I, Downie A, Joseph S (2007) Agronomic values of greenwaste biochar as a soil amendment. Aust J Soil Res 45:629-634

Chan KY, Van Zwieten L, Meszaros I, Downie A, Joseph S (2008) Using poultry litter biochars as soil amendments. Aust J Soil Res 46:437-444

Christensen ML, Sommer SG (2013) Manure characterization and inorganic chemistry. In: Sommer SG, Christensen ML, Schmidt T, Jensen LS (eds) Animal manure: recycling, treatment and management. Wiley, United Kingdom, pp 41-66

Cross AF, Schlesinger WH (1995) A literature review and evaluation of the Hedley fractionation: applications to the biogeochemical cycle of soil phosphorus in natural cosystems. Geoderma 64:197-214

Dalólio FS, da Silva JN, de Oliveira ACC, Tinôco IFF, Barbosa RC, Resende MO, Albino LFT, Coelho ST (2017) Poultry litter as biomass energy: a review and future perspectives. Renew Sust Energ Rev 76:941-949

Demirbas A (2004) Effects of temperature and particle size on bio-char yield from pyrolysis of agricultural residues. J Anal Appl Pyrol $72: 243-248$

Di Blasi C, Signorelli G, Di Russo C, Rea G (1999) Product distribution from pyrolysis of wood and agricultural residues. Ind Eng Chem Res 38:2216-2224

Dou Z, Toth JD, Galligan DT, Ramberg CF Jr, Ferguson JD (2000) Laboratory procedures for characterizing manure phosphorus. $\mathrm{J}$ Environ Qual 29:508-514

Edwards DR, Daniel TC (1992) Environmental impacts of on-farm poultry waste disposal-a review. Bioresour Technol 41:9-33

Enders A, Hanley K, Whitman T, Joseph S, Lehmann J (2012) Characterization of biochars to evaluate recalcitrance and agronomic performance. Bioresour Technol 114:644-653

Florin NH, Maddocks AR, Wood S, Harris AT (2009) High-temperature thermal destruction of poultry derived wastes for energy recovery in Australia. Waste Manag 29:1399-1408

Glaser B, Lehmann J, Zech W (2002) Ameliorating physical and chemical properties of highly weathered soils in the tropics with charcoal-a review. Biol Fertil Soils 35:219-230

Glazunova DM, Kuryntseva PA, Selivanovskaya SY, Galitskaya PY (2018) Assessing the potential of using biochar as a soil conditioner. IOP Conf Ser: Earth Environ Sci 107:012059

Gonzalez RZ, Woods RE (2008) Digital image processing, 3rd edn. Prentice Hall, Upper Saddle River

Gray M, Johnson MG, Dragila MI, Kleber M (2014) Water uptake in biochars: the roles of porosity and hydrophobicity. Biomass Bioenergy 61:196-205 
Halverson C, White DJ, Gray J (2005) Application of x-ray CT scanning to characterize geomaterials used in transportation construction. In: Proceedings of the 2005 Mid-Continent Transportation Research Symposium, Iowa State University

Hapca SM, Houston AN, Otten W, Baveye PC (2013) New local thresholding method for soil images by minimizing grayscale intra-class variance. Vadose Zone J 12(vzj2012):0172

Hilpert M, Miller CT (2001) Pore-morphology-based simulation of drainage in totally wetting porous media. Adv Water Resour 24:243-255

Hyväluoma J, Hannula M, Arstila K, Wang H, Kulju S, Rasa K (2018a) Effects of pyrolysis temperature on the hydrologically relevant porosity of willow biochar. J Anal Appl Pyrol 134:446-453

Hyväluoma J, Kulju S, Hannula M, Wikberg H, Källi A, Rasa K (2018b) Quantitative characterization of pore structure of several biochars with 3D imaging. Environ Sci Pollut Res 25:25648-25658

Iassonov P, Tuller M (2010) Application of segmentation for correction of intensity bias in X-ray computed tomography images. Vadose Zone J 9:187-191

Ibarra JV, Bonet AJ, Moliner R (1994) Release of volatile sulfur compounds during low temperature pyrolysis of coal. Fuel 73:933-939

Jeffery S, Verheijen FGA, van der Velde M, Bastos AC (2011) A quantitative review of the effects of biochar application to soils on crop productivity using meta-analysis. Agric Ecosyst Environ 144:175-187

Jeffery S, Meinders MBJ, Stoof CR, Bezemer T, van de Voorde TFJ, Mommer LJ, van Groenigen JW (2015) Biochar application does not improve the soil hydrological function of a sandy soil. Geoderma 251-252:47-54

Jones K, Ramakrishnan G, Uchimiya M, Orlov A (2015) New applications of X-ray tomography in pyrolysis of biomass: biochar imaging. Energy Fuels 29:1628-1634

Kistler RC, Widmer F, Brunner PH (1987) Behavior of chromium, nickel, copper, zinc, cadmium, mercury, and lead during the pyrolysis of sewage sludge. Environ Sci Technol 21:704-708

Kloss S, Zehetner F, Dellantonio A, Hamid R, Ottner F, Liedtke V, Schwanninger M, Gerzabek MH, Soja G (2012) Characterization of slow pyrolysis biochars: effects of feedstocks and pyrolysis temperature on biochar properties. J Environ Qual 41:990-1000

Laghari M, Mirjat MS, Hu Z, Fazal S, Xiao B, Hu M, Chen Z, Guo D (2015) Effects of biochar application rate on sandy desert soil properties and sorghum growth. Catena 135:313-320

Laird DA, Brown RC, Amonette JE, Lehmann J (2009) Review of the pyrolysis platform for coproducing bio-oil and biochar. Biofuel Bioprod Biorefin 3:547-562

Lei O, Zhang R (2013) Effects of biochars derived from different feedstocks and pyrolysis temperatures on soil physical and hydraulic properties. J Soils Sediments 13:1561-1572

Liang H, Chen L, Liu G, Zheng H (2016) Surface morphology properties of biochars produced from different feedstocks. In: Proceedings of the 2016 International Conference on Civil, Transportation and Environment. https://doi.org/10.2991/iccte-16.2016.210

Libra JA, Ro KS, Kammann C, Funke A, Berge ND, Neubauer Y, Titirici M-M, Fühner C, Bens O, Kern J, Emmerich K-H (2011) Hydrothermal carbonization of biomass residuals: a comparative review of the chemistry, processes and applications of wet and dry pyrolysis. Biofuels 2:71-106

Lievens C, Yperman J, Vangronsveld J, Carleer R (2008) Study of the potential valorisation of heavy metal contaminated biomass via phytoremediation by fast pyrolysis: part I. Influence of temperature, biomass species and solid heat carrier on the behaviour of heavy metals. Fuel 87:1894-1905

Lima IM, Ro KS, Reddy GB, Boykin DL, Klasson KT (2015) Efficacy of chicken litter and wood biochars and their activated counterparts in heavy metal clean up from wastewater. Agriculture 5:806-825

MAF, Ministry of Agriculture and Forestry (Finland) (2018) Assessment of risks related to increasing heavy metal limits for fertilizers in Finland. Publ Minist Agric For 2(2018):80

Mallin MA, Cahoon LB (2003) Industrialized animal production-a major source of nutrient and microbial pollution to aquatic ecosystems. Popul Environ 24:369-385

Martinez J, Dabert P, Barrington S, Burton C (2009) Livestock waste treatment systems for environmental quality, food safety, and sustainability. Bioresour Technol 100:5527-5536

Moore PA Jr, Daniel TC, Sharpley AN, Wood CW (1995) Poutry manure management: environmentally sound options. J Soil Water Conserv 50:321-327

Mukherjee A, Zimmermann AR, Harris W (2011) Surface chemistry variations among a series of laboratory-produced biochars. Geoderma 163:247-255

Mukome FND, Zhang X, Silva LCR, Six J, Parikh SJ (2013) Use of chemical and physical characteristics to investigate trends in biochar feedstocks. J Agric Food Chem 61:2196-2204

Nicholson FA, Chambers BJ, Smith KA (1996) Nutrient composition of poultry manures in England and Wales. Bioresour Technol $58: 279-284$

Nicholson FA, Chambers BJ, Williams JR, Unwin RJ (1999) Heavy metal contents of livestock feeds and animal manures in England and Wales. Bioresour Technol 70:23-31

Novak JM, Lima I, Xing B, Gaskin JW, Steiner C, Das KC, Ahmedna M, Rehrah D, Watts DW, Busscher WJ, Schomberg H (2009) Characterization of designer biochar produced at different temperatures and their effects on a loamy sand. Ann Environ Sci 3:195-206

Novak JM, Cantrell KB, Watts DW (2013) Compositional and thermal evaluation of lignocellulosic and poultry litter chars via high and low temperature pyrolysis. Bioenergy Res 6:114-130

Novak JM, Cantrell KB, Watts DW, Busscher WJ, Johnson MG (2014) Designing relevant biochars as soil amendments using lignocellulosic-based and manure-based feedstocks. J Soils Sediments $14: 330-343$

Oenema O (2004) Governmental policies and measures regulating nitrogen and phosphorus from animal manure in European agriculture. J Animal Sci 82(E. Suppl):E196-E206

Omondi MO, Xia X, Nahayo A, Liu X, Korai PK, Pan G (2016) Quantification of biochar effects on soil hydrological properties using meta-analysis of literature data. Geoderma 274:28-34

Otero M, Sánchez ME, Gómez X (2011) Co-firing of coal and manure biomass: a TG-MS approach. Bioresour Technol 102:8304-8309

Otsu N (1979) A threshold selection method from gray-level histograms. IEEE Trans Syst Man Cybern 9:62-66

Paneque M, De la Rosa JM, Kern J, Reza MT, Knicker H (2017) Hydrothermal carbonization and pyrolysis of sewage sludges: What happen to carbon and nitrogen? J Anal Appl Pyrol 128:314-323

Park JH, Choppala GK, Bolan NS, Chung JW, Chuasavathi T (2011) Biochar reduces the bioavailability and phytotoxicity of heavy metals. Plant Soil 348:439-451

Paudel KP, Bhattarai K, Gauthier WM, Hall LM (2009) Geographic information systems (GIS) based model of dairy manure transportation and application with environmental quality consideration. Waste Manag 29:1634-1643

Pels JR, Kapteijn F, Moulinjn JA, Zhu Q, Thomas KM (1995) Evolution of nitrogen functionalities in carbonaceous materials during pyrolysis. Carbon 33:1641-1653

Potter P, Ramankutty N, Bennet EM, Donner S (2010) Characterizing the spatial patterns of global fertilizer application and manure production. Earth Interact 14:1-22

Qiu G, Guo M (2010) Quality of poultry litter-derived granular activated carbon. Bioresour Technol 101:379-386 
Rasa K, Heikkinen J, Hannula M, Arstila K, Kulju S, Hyväluoma J (2018) How and why does willow biochar increase a clay soil water retention capacity? Biomass Bioenerg 119:346-353

Ren Q, Zhao C (2012) $\mathrm{NO}_{\mathrm{x}}$ and $\mathrm{N}_{2} \mathrm{O}$ precursors from biomass pyrolysis: nitrogen transformation from amino acid. Environ Sci Technol 46:4236-4240

Ro KS, Cantrell KB, Hunt PG (2010) High-temperature pyrolysis of blended animal manures for producing renewable energy and value-added biochar. Ind Eng Chem Res 49:10125-10131

Schmidt H-P, Pandit BH, Cornelissen G, Kammann CI (2017) Biochar-based fertilization with liquid nutrient enrichment: 21 field trials covering 13 crop species in Nepal. Land Degrad Dev 28:2324-2342

Schnee LS, Knauth S, Hapca S, Otten W, Eickhorst T (2016) Analysis of physical pore space characteristics of two pyrolytic biochars and potential as microhabitat. Plant Soil 408:357-368

Sharpley A, Moyer B (2000) Phosphorus forms in manure and compost and their release during simulated rainfall. J Environ Qual 29:1462-1469

Sommer SG, Christensen ML (2013) Animal production and animal manure management. In: Sommer SG, Christensen ML, Schmidt $\mathrm{T}$, Jensen LS (eds) Animal manure: recycling, treatment and management. Wiley, United Kingdom, pp 5-24

Sommer SG, Oenema O, Matsunaka T, Jensen LS (2013) Regulations on animal manure management. In: Sommer SG, Christensen ML, Schmidt T, Jensen LS (eds) Animal manure: recycling, treatment and management. Wiley, United Kingdom, pp 25-40

Song W, Guo M (2012) Quality variations of poultry litter biochar generated at different pyrolysis temperatures. J Anal Appl Pyrol 94:138-145

Sørensen JT, Edwards S, Noordhuizen J, Gunnarsson S (2006) Animal production systems in the industrialised world. Scientific Technical Review of the Office International des Epizooties 25:493-503

Spokas KA (2010) Review of the stability of biochar in soils: predictability of O:C molar ratios. Carbon Manag 1:289-303

Stephenson AH, McCaskey TA, Ruffin BG (1990) A survey of broiler litter composition and potential value as a nutrient resource. Biological Wastes 34:1-9
Szogi AA, Vanotti MB (2009) Prospects for phosphorus recovery from poultry litter. Bioresour Technol 100:5461-5465

Turpeinen T (2015) Analysis of microtomographic images of porous heterogeneous materials. PhD thesis, University of Jyväskylä. Jyväskylä Studies in Computing 230

Verheijen F, Jeffery S, Bastos AC, van der Velde M, Diafas I (2010) Biochar application to soils - a critical scientific review of effects on soil properties, processes and functions. EUR $24099 \mathrm{EN}$, Office for the Official Publications of the European Communities, Luxembourg

Vogel H-J, Roth K (1998) A new approach for determining effective soil hydraulic functions. Eur J Soil Sci 49:547-556

Vogel H-J, Weller U, Schlüter S (2010) Quantification of soil structure based on Minkowski functions. Comput Geosci 36:1236-1245

Wang T, Camps-Arbestein M, Hedley M, Bishop P (2012) Predicting phosphorus bioavailability from high-ash biochars. Plant Soil 357:173-187

Wang Y, Lin Y, Chiu PC, Imhoff PT, Guo M (2015) Phosphorus release behaviors of poultry litter biochar as a soil amendment. Sci Total Environ 512-513:454-463

Wang J, Xiong Z, Kuzyakov Y (2016) Biochar stability in soil: metaanalysis of decomposition and priming effects. Glob Change Biol Bioenergy 8:512-523

Woolf D, Amonette JE, Street-Perrott FA, Lehmann J, Joseph S (2010) Sustainable biochar to mitigate global climate change. Nat Commun 1(56):1-9

Ylivainio K, Uusitalo R, Turtola E (2008) Meat bone meal and fox manure as $\mathrm{P}$ sources for ryegrass (Lolium multiflorum) grown on a limed soil. Nutr Cycl Agroecosys 81:267-278

Yuan J-H, Xu R-K, Zhang H (2011) The forms of alkalis in the biochar produced from crop residues at different temperatures. Bioresour Technol 102:3488-3497

Zornosa R, Moreno-Barriga F, Acosta JA, Muñoz MA, Faz A (2016) Stability, nutrient availability and hydrophobicity of biochars derived from manure, crop residues, and municipal solid waste for their use as soil amendments. Chemosphere 144:122-130 